\title{
Fractionated megacryst-mineral suites from the Luxinga kimberlite cluster, Angola
}

\author{
A.J. Rogers ${ }^{1}$, H.S. Grutter ${ }^{2}$, and J. Twidale ${ }^{3}$ \\ ${ }^{I}$ Petra Diamonds, Block 3, Silver Point Office Park, 22 Ealing Crescent, Bryanston, Johannesburg, South Africa \\ ${ }^{2}$ BHP Billiton World Exploration inc., \#800 Four Bentall, 1055 Dunsmuir St., Vancouver, B.C., V7X 1L2, Canada \\ ${ }^{3}$ BHP Billiton World Exploration inc., 6 Hollard St., Marshalltown, Johannesburg, South Africa
}

\begin{abstract}
Introduction
The Luxinga kimberlite cluster occupies an area of approximately $30 \mathrm{~km} \times 15 \mathrm{~km}$, and forms part of a larger kimberlite field that is partially covered by the Alto Cuilo exploration project, located in the Lunda Sul province of NE Angola. In light of the large number of kimberlite-like geophysical anomalies identified through airborne magnetic surveys (over 200) and verified by narrow-diameter NQ core drilling (80 larger than 5 hectares); Heavy Mineral Analysis (HMA) of Kimberlite Indicator Minerals (KIM) has been used as a tool to prioritize drill-confirmed kimberlite bodies for follow-up investigation and additional drilling. The prioritization is based largely on the diamond potential inferred from the abundance and chemical composition of mantle-derived garnets in the drill-confirmed kimberlites. The garnet-based assessments are independently verified by results for (ideally) $200 \mathrm{~kg}$ microdiamond (MiDa) samples collected from the same geological units.
\end{abstract}

\section{Data set and methodology}

This work draws on industry-standard electron microprobe analysis of over 40,000 garnet xenocryst grains representing 55 drill-confirmed kimberlite bodies that occur across the whole Alto Cuilo project. We focus in particular on some 9000 garnet analyses from 36 representative HMA samples that represent 18 kimberlites from the Luxinga-area kimberlite cluster. The exploration geology and setting of these kimberlites is described in some detail in a related contribution to 9IKC (Eley et al., 2008). Garnet compositions were classified strictly according to the scheme of Grutter et al. (2004), with diamond potential assessed according to the abundance of categories G10D, G3D, G4D and G5D. As shown below, the latter three categories require small modifications to published compositional boundaries, in order to correct for the abundance of evolved, Fe-rich garnet megacryst compositions in Luxinga-area kimberlites. The megacryst association is amplified further by 450 additional analyses for ilmenite xenocrysts from 3 Luxinga-area kimberlites, as well as 5 ilmenites found as inclusions within microprobe-confirmed G1 (megacrystic) garnets.

\section{Results and Discussion}

\section{Ilmenites}

Fig. 1 shows that ilmenite xenocrysts generally have a typical kimberlite megacryst compositions, with low $\mathrm{Cr}$ content (generally $<1 \% \mathrm{Cr}_{2} \mathrm{O}_{3}$ ), and $\mathrm{MgO}$ ranging from $4 \%-12 \%$. A small percentage of ilmenites, specifically recovered from kimberlite $\mathrm{AC} 243$, fall to low $\mathrm{MgO}$ inside the "non-kimberlitic" field on the $\mathrm{TiO}_{2}-\mathrm{MgO}$ diagram of Wyatt et al. (2004). These analyses all show elevated $\mathrm{MnO}$ content. Two of the five microprobeconfirmed ilmenite inclusions in megacryst garnets have low- $\mathrm{Cr}_{2} \mathrm{O}_{3}$, and $\mathrm{MgO}$ compositions typical of megacryst ilmenite (Fig. 1), but the remaining three inclusions are displaced to lower $\mathrm{MgO}$, and also have elevated $\mathrm{MnO}$ content. The xenocryst and megacrystincluded ilmenites with elevated $\mathrm{MnO}$ are from the same kimberlite (AC 243), implying that these grains should be interpreted as megacrystic, kimberlitic grains with elevated $\mathrm{MnO}$ content attributed to secondary alteration.

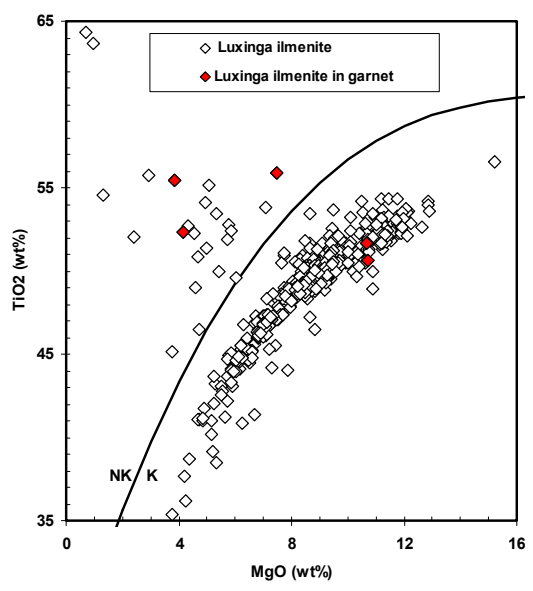

Fig. $1 \mathrm{TiO}_{2}-\mathrm{MgO}$ diagram after Wyatt et al. (2004), showing ilmenite compositions for discrete grains and inclusions in G1 megacrystic garnets. Grains from AC243 fall in the non-kimberlitic field. 


\begin{tabular}{|c|c|c|c|c|c|c|c|c|c|}
\hline \multirow{2}{*}{ Sample } & \multicolumn{8}{|c|}{ Garnet Counts from HMA Sample Splits } & \multirow{2}{*}{ MiDa } \\
\hline & G10 & G10D & G9 & 'G9D' & G5/G4/G3 & G5D/G4D/G3D & G1 & G1R & \\
\hline AC037-1-1 & 13 & 9 & 206 & 8 & 12 & 12 & 15 & 15 & $223.5 \mathrm{Kg}$, weak \\
\hline AC055-2-1 & 23 & 2 & 276 & 24 & 60 & 0 & 18 & 10 & No sample \\
\hline AC056-1-2 & 16 & 0 & 211 & 4 & 23 & 21 & 75 & 42 & No sample \\
\hline AC122-1-1 & 1 & 0 & 104 & 2 & 5 & 0 & 12 & 2 & No sample \\
\hline AC130-1-1 & 29 & 1 & 73 & 2 & 12 & 1 & 18 & 2 & $195 \mathrm{Kg}$, negative \\
\hline AC131-1-1 & 0 & 0 & 14 & 0 & 3 & 0 & 14 & 5 & No sample \\
\hline AC132-1-3 & 10 & 1 & 63 & 5 & 41 & 2 & 61 & 33 & No sample \\
\hline AC136-1-1 & 4 & 46 & 63 & 66 & 10 & 30 & 121 & 33 & No sample \\
\hline AC139-2-2 & 0 & 0 & 0 & 0 & 1 & 0 & 20 & 2 & No sample \\
\hline AC152-3-1 & 2 & 0 & 26 & 5 & 5 & 1 & 0 & 0 & No sample \\
\hline AC171-2-1 & 0 & 0 & 0 & 0 & 23 & 0 & 5 & 0 & $204.4 \mathrm{Kg}$, weak \\
\hline AC178-1-1 & 3 & 1 & 18 & 2 & 17 & 1 & 1 & 2 & No sample \\
\hline AC197-1-1 & 16 & 3 & 224 & 23 & 58 & 9 & 0 & 0 & $200.5 \mathrm{Kg}$, fair \\
\hline AC201-1-1 & 4 & 0 & 40 & 0 & 55 & 12 & 20 & 11 & No sample \\
\hline AC243-1-1 & 8 & 0 & 228 & 4 & 70 & 11 & 18 & 48 & No sample \\
\hline AC254-5-1 & 20 & 1 & 259 & 7 & 83 & 8 & 56 & 11 & $202.8 \mathrm{Kg}$, weak \\
\hline
\end{tabular}

Table 1 Tabulation of garnet classes for garnets from representative Luxinga kimberlites. G0, G11, and G12 classes are not represented. 'G9D' represents G9 garnets with $<0.36 \mathrm{wt} \% \mathrm{MnO}$.

\section{Garnets}

Table 1 summarizes garnet grain classifications by HMA sample from the Luxinga cluster. The proportion of G1-classified megacryst garnets varies from $0 \%$ of the representative garnet sample at AC55 to $32 \%$ at AC136. In Table 1, the abundance of "diamond-facies" eclogitic/websteritic/pyroxentic grains (G3D, G4D and G5D classifications) appears to roughly correlate with the abundance of megacrystic G1 garnets for the majority of samples, yet samples from certain kimberlites (AC56, AC243 and AC201) show little or no evidence of the presence of diamond-facies peridotitic garnets $(\mathrm{G} 10 \mathrm{D}$, or G9 with $\mathrm{MnO}<0.36$ $\mathrm{wt} \%$ ). This presents a problem under the current understanding of diamond paragenesis - how can eclogitic and websteritic garnets be predominantly derived from within the Diamond Stability Field (DSF) if the dominant peridotitic garnets are derived from outside the Diamond Stability Field?

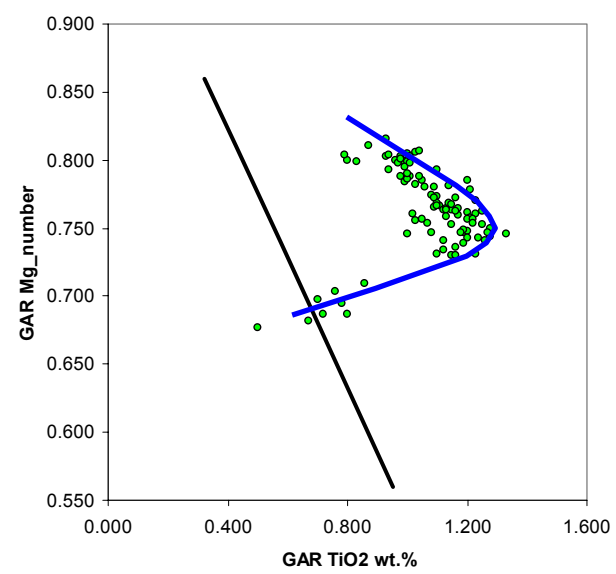

Fig. $2 \mathrm{TiO}_{2}$ vs. Mg_number plot for megacryst (G1) garnets from Monastery and various northern Lesotho kimberlites. The black line represents one of the exisiting G1 classification criteria of Grutter et al. (2004). Data from Bell and Rossman (1992), Nixon and Boyd (1973), and Schulze (1997).
Assuming no uncertainty on classification of diamondfacies low-Cr garnets, this paradox could be entertained if a discrete mantle layer comprising 100\% eclogite-websterite-pyroxenite is situated deeper than common mantle peridotite, all of which occurs entirely within the graphite stability field. This notion is not supported by low microdiamond counts for most of the MiDa samples from the Luxinga area (Table 1). On closer inspection of available compositional data it is evident that garnet megacrysts from the Luxinga-area kimberlites show extreme fractionation trends, matched only by megacryst compositions from a few select localities in Southern Africa, e.g. Monastery (Figs. 2 and 3, Schulze 1997). The Luxinga garnet megacrysts range to lower Mg-numbers than are common; they are strongly fractionated (Fe-rich) and reach low $\mathrm{Cr}_{2} \mathrm{O}_{3}$ and low-end $\mathrm{TiO}_{2}$ values at $\mathrm{Mg} \_$numbers below about 0.69 . At this point the existing garnet classification scheme of Grutter et al. (2004) incorrectly assigns a diamondfacies G3D, G4D or G5D designation to garnet xenocrysts that actually should be characterized as high-Na, Fe-rich megacrysts. Plots of megacryst garnets from Luxinga and various Southern African examples are shown in Figs. 2 and 3.

In order to remedy apparent misclassification and improve assessment of true diamond-facies garnet xenocrysts at Alto Cuilo, we have instituted a new "G1R" garnet category. A "G1 reclassified" garnet complies with the following empirical criteria, and should be applied to garnets classifying as G3, G3D, G4, G4D, G5, G5D in Grutter et al (2004).

$\mathrm{Mg}$ _number $<0.24 * \mathrm{TiO}_{2}+0.66$

$\mathrm{Mg} \_$number $>1.7-3 * \mathrm{TiO}_{2}$

$\mathrm{Mg}$ _number $>0.55$ 


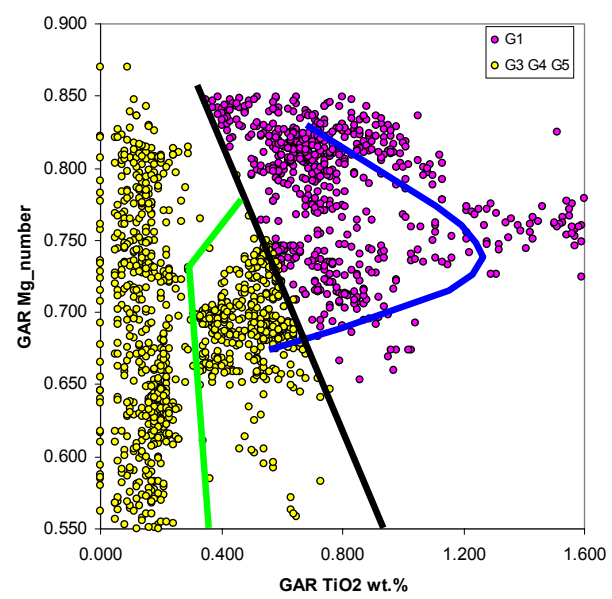

Wyatt, B.A., Baumgartner, M., Anckar, E., Grutter, H. 2004. Compositional classification of "kimberlitic and "non-kimberlitic" ilmenite. Lithos 77, 841-857.

Fig. $3 \mathrm{TiO}_{2}$ vs. Mg_Number plot for G1, G3, G4, and G5 garnets from Luxinga $(n=2273)$. The blue curve represents the Monastery and N. Lesotho megacryst trend, while the black line is one of the G1 classification criteria of Grutter et al. (2004). Lime green lines classify G1R garnets from this study (shown here as G3 G4 or G5 garnets that lie within the field defined by the aforementioned boundaries.)

\section{Conclusions}

After instituting this reclassification, we find that the abundance of "diamond-facies" garnets in Luxingaarea kimberlites drops significantly in most cases, in acceptable agreement with available microdiamond data (Table 1). The G1R classification also eliminates some high-Na grains (up to $0.19 \mathrm{wt} \% \mathrm{Na}_{2} \mathrm{O}$ ) that plot well inside the DSF field on a $\mathrm{TiO}_{2}-\mathrm{Na}_{2} \mathrm{O}$ plot from kimberlites with better peridotitic signatures (AC37 and AC136), reducing their apparent diamond potential.

\section{References}

Bell, D.R., Rossman, G.R., 1992. The distribution of hydroxyl in garnets from the subcontinental mantle of Southern Africa. Contributions to Mineralogy and Petrology (111). 161-178.

Eley R., Grütter H, Louw A., Tunguno C., Twidale J., 2008 .Exploration Geology of the Luxinga Kimberlite Cluster (Angola) with Evidence Supporting the Presence of Kimberlite Lava. $9^{\text {th }}$ International Kimberlite Conference Extended Abstract No. 9IKC-A-00166

Grutter, H.S., Gurney, J.J., Menzies, A.H., Winter, F. 2004. An updated classification scheme for mantlederived garnets for use by diamond explorers Lithos 77 (2004), 841-857.

Nixon, P.H., Boyd, F.R., 1973. Carbonated ultrabasic nodules from Sekameng. In: Nixon, P.H. (ed.) Lesotho Kimberlites, Lesotho National Development Corporation, Maseru, 190-196.

Schulze, D.J. 1997. The significance of eclogite and Cr-poor megacryst garnets in diamond exploration. Exploration and Mining. Geology( 6). 349-366. 